\title{
EVALUATION OF HYGIENIC QUALITY OF BURGER IN TWO PROCESSING PLANTS IN ALEXANDRIA PROVINCE
}

\author{
Wafaa M. M. Elssa and Nabila F. Sollman \\ AnImal Health Research Institute, Alexandra Provincial Lab. \\ Food Hygiene Research Unit
}

\begin{abstract}
The evaluation of hygienic quality of burger (frozen meat product) in tuo parallel flows pracessing of meat products in Alexandria province. One fow of meat produced according to the new safety assurance, superior system will extst plant (A). The other fow will consist of meat produced and inspected in the traditional way. This study was done through bacterlologicul exarnination of meat. product and contact surroundings (swabs of workers, walls and machines). Bacteriologtcal examination of samples included total bacterial caunt, besides isolation of Staphylococciss aureus and Salmonellae of both frozen raw meat and flnished burger products. Monitoring system that keeps track of the umportant heaith hazards in the entire chaln from raw meat till ready to eat meat. Results revealed that the bacteriological quality of raw meat in both plants within the acceptable limit but it is slighlly exceed in plant (B) and presence of Staphybcocct. Bacteriological results of final burger products samples in plant (A) within the - legal limit of APC, while in plant B most samples reach the top of acceptable limit of APC and S. aureus isolated from $70 \%$ of samples. Salmonellae could not be detected in all examined samples. Results of swabs from food contact surroundings indicated that plant (A) was lower than plant (B) in $A P C$ of swabs of workers, walls and machlnes. The whole system of plant $(B)$ is conductive to microblological growth. Our results of final burger product samples of APC after grill of both plants were good depending the the and method of cooking. Some recommendattons have been Jormulated at the industry's level, at the institutional level and hygienic requirements needed to produce safe and good quality burger in both plants were discussed to by implemented.
\end{abstract}

\section{INTRODUCTION}

In recent decades. the Increase of human population in relation to the great development in human life caursed a great demand of easily prepared meals contalned high level of animal proteln. However, meat products are generally excellent sources of protein contain-
Ing a good balance of the essential amino acIds and having a high blological value. It is a good source of most B-complex vitamins and also contributes significant percentage of minerals Inclutding iron, copper, zinc, sodlum. potasslum and magneslum. which are essential for growth and health of human beings. 
Technological development in meat processing and handling have given consumers a much greater cholce over the food they can buy. So meat hyglene can comprise nearly every aspect of proeessing from the health of the live animal to the distribution of the nnal product. it prevents harmful ingredients manufactured meat products and the sale of con. taminated or unwholesome meat.

The effects of hazards on human health assoetated with lood, the increasing importance and rapid growth of world food trade and the demand by consumers for a safe rood supply make the analysis of the hazards (rsks) assoelated with food more important today than ever before.

The analysis and the dcvelopment of organized programs to ellininate such hazards or control within aeeeptable limits those risks not possible to eliminate, have been designated as Hazard Analysis and Crilical Control Point (HACCP) systeill.

Beef burgers are highly demanded due to their high blologlcal value, reasonable price. agreed taste and ease of serving. It is consid. cred as an excellent source of high quality protein.

Beef burgers are grind frozen formulated meat formed in constant clrcular shape. thickness and weight to be served to general publle in high volume fast food operation in whieh frozen burgers are recelved, cooked and served in few minutes of eooking.

Beer burger as meat products are subjected to strict quality ehecks, to ensure that the products meet the agreed quality standards. These have to be right first time, every tIme. this quality control which involve inspection and testing at the end of the manufacturing proeess.

Proeessed meat products may at time constututes a publie health hazard due to presenee of spollage microorganisms responsible for objectionable ehanges or pathogente leading to infeetion and intoxication.

A polluted environment and lack sanitation increases the likelihood of a food contaminaton. In countries where food eontrol is weak beeause of lack of resources, edueatlon of consumers and food handlers in food safety glves them the knowledge to be selective when ehoosing food and to refuse lood that is of doubtrul hyglentc quality (WHO. 2000).

The quality of a product may be deflned as its measurement against a standard regarded as excellent at a particular price which is satIsfactory both to the producer and to the consumer.

It has bcen claimed that the eflelency of microbiological control can be improved signineantly by a logical and systematic stepwise analysis of the risks involved in any process.

Meat and meat products are liable to be contarninated with different types of microorganisms from different sources. Such eontamination may be of publie health hazard to consumers or may render the products unmarketable especially in small ractorles. In which the hyglenic measures are still underway. Therefore, one of the maln responsiblli- 
ties of the meat technologists and scientists are to find the best posslble way to produce a product free from pathogens of public heaith hazard and with luw microblal contents in order to improve its quality. Heat treatment (grill) had a signincant effect on bactcriological quality of the beef burger.

The Alm of thls work was to Investigation of the hyglenic quality of bcef burger in plant that applying quality assurance program as well as in a traditional plant, the importance of good manufacturing practices (GMP) and quality control in all stages of production of meat according to the princlples of Hazard Analysis and Critical Control Polnts (HACCP) is advised.

\section{MATERIAL AND METHODS Collection of aamplea: \\ Preparation of namplea}

A total of threc hundreds random samples were collected from two manufacturing plants. First plant (plant A). applying a new safety assurance. superlor system during processing. while the second plant (plant B) contalned a meat produced and inspected in the traditional way.

The collectcd samples were frozen raw meat (resembling 25 batches). fnal product and after grill (25 samplcs of each). Thc samples were thoroughly mixed and $25 \mathrm{~g}$. wcre homogenlzed in $225 \mathrm{ml}$ of 0.196 sterlle peptone water in disposable sterlle plastic bag in stomacher lab blender for 30 seconds to glve a dilution of $1 / 10$ then the decimal dilutions up to $10^{-5}$ were prepared. $1 \mathrm{ml}$ from each $\mathrm{dl}$ lution was tranglened with the sterilc $1 \mathrm{mi}$ pl. pette to each two separate sterlle petridishes.
Colonies were counted and recorded as the total colony per gram of sample also swabs of workers, walls, machines (calculated colony/ $\mathrm{cm}^{2}$ ) from each plant.

The samples were directly transferred to the laboratory in an insulated ice box under aseptic conditions without any delay for the following bactcrlological examination.

a- Determination of total aerobic bacterial count according to the technique recommended by APHA (1892).

b- Isolation and Identincation of Staphylococcus aureus was carrled out according to ICMSF (1996).

c- Detection of Salmonellae: according to Vagstwiaditg et al. (1983).

Flow chart shows the unit operatlons in burger manufactures. Recelving and storage of raw meat $\rightarrow$ Deboxing of frozen meat $\rightarrow$ In!thal grind $\rightarrow$ batch formulation $\rightarrow$ meat blendcd in mLxer/grinders $\rightarrow$ transfer to formers $\rightarrow$ forming $\rightarrow$ freezing tunncls $\rightarrow$ packing $\rightarrow$ frozen storage.

\section{RESLLTS}

The data lllustrated in table (1) revealed that the total aerobic plate counts (APC) of examined frozen raw meat in plant (A) ranged from $1.1 \times 10$ to $2.4 \times 10^{2}$ with a mean value of $5.5 \times 10 \pm 1.1 \times 10$, while in plant (B), were $1.3 \times 10-3.1 \times 10^{2}$ with a mcan value of 6.28 $\times 10 \pm 1.32 \times 10$.

T. test connrmed that there was no signillcant difference of APC In examined raw meat samples in both plants. Staphylococeus aureus eould not be detected in plani (A), whlle in plant (B), each constituting 20\%. Salmonellae 
falled to be isolated from both plants. These results with In the aeeeptable limlt of Egyptian standard for frozen raw meat.

The data present in table (2) indicated that APC In final product samples in plant (A) ranged from $2.4 \times 10^{2}$ to $2.6 \times 10^{2}$ with mean value $8.71 \times 10^{2} \pm 1.44 \times 10^{2}$.

On the other hand, In plant (B) ranged between $2.4 \times 10^{4}$ and $3.5 \times 10^{5}$ with a higher mean value $10.82 \times 10^{4} \pm 1.73 \times 10^{4}$. Most samples reached the top of acceptable limit. There are significant differences in APC of examined samples between plant $(A)$ and plant (B) at $P<0.05$. Staphylocoecus aureus could not be detected In plant (A) whlle in plant (B) It was detected in high incidence, constituting $70 \%$ of eollected samples.

Salmonellae falled to be detected from both plants. Results wcre compared with Egyptian standard for requirement of burger.

The results obtalned in table (3) showed that APC of swabs collected from food contact surroundings: hand of workers. walls, and contact surfaces machlnes were $1 \times 10^{-1} \mathrm{x}$ $10^{2}$ with mean value $4.4 \times 10 \pm 0.62 \times 10,0$ 10 with a mean value $5.2 \pm 1.0^{2}$ and $0-10$ wth mean value $6.4 \pm 0.98$ in plant (A), respectively; whlle in plant (B) were from $1 \mathrm{x}$ $10^{2}-1 \times 10^{5}$ with mean value $3.68 \times 10^{3} \pm$ $2.014 \times 10^{3} .0-10$ with mean value $6.4 \pm$ $0.98: 1 \times 10^{-1} \times 10^{3}$ with mcan value $2.58 \times$ $10^{2} \pm 7.6 \times 10$ : respectuvely.

The data present in tabic (4) revealed that the range and mean values of APC of samples after grill in plant (A) were 0-8, 2.28 0.47 . whlle in plant (B) ranged from $1 \times 10^{-8} \times 10$ with mean value $3.88 \times 10 \pm 0.44 \times 10$.

\section{DISCUSSION}

For a long time baeterlological techniques have been successfully employed to evaluate the microblal quality of beef burger and to determine the effect of microblal load on shelf life of these products. The bacterlal population in ground meat reflects the bacterlologlcal quallty of meat used for grinding, cleanllness of equipment, the time and temperature of storage samples of ground beef are clearly Indicative of the history of the product.

The obtained results, revealed that frozen raw meat in plant (A) and plant (B) showed nearly simtlar APC the applied statistical ttest confirmed that there was no significant differences, and both within the acceptable limit of APC stipulated by the Egyptian Standard for frozen raw meat.

The total colony count gives an Idea about the hygjenlc measures applied during processing and also help In the determination of the keeping quallty of the meat. So, the total colony count was the most rellable method for detection of sanitary processing of proper storage of food production.

Results showcd that frozen raw mcat in plant (A) was free from Staphylococcus aureus, while in plant (B). it was detected in $20 \%$ of examined samples. Thesc results nearly simllar to Tolba (1804) and Badary (2004) which isolated this microorganism in food polsoning outbreaks, equipment, envronmental surfaces can also be sourccs of contamination and may be due to lat the 
point of dellvery). The meat is holsted onto the shoulders of a porter wearing a dirty blood stained coat.

Our results confirmed that Salmonellae fatled to be detected in all stcps of processing of burger samples of both plants .

This spollage can be occurred from certaln miero-organisms which rapidly multiply and caused discase. This can be dangerous as under unsanitary conditions and improper temperalure control doubles in number every 20 minutes. This agrees with that reported by (Marriot, 1994).

Results revealed that the mean value of APC of examined Anal burger product samples of plant (A) within the acceptable llmlt of ES requirements, nearly simtlar results obtained by Mohammed (1897) but lower than Amal E1- 8herlf (1983), Yagslen (1988) Staphylococeus aureus falled to be detected in plant (A), this may be due to application of total commitment of management and employees to hyglene and even beyond (food handlers usually with good hyglene seores): design. environment, equlpment, waste disposal system and operations under control; tollet and hand-washing factlitles in working eondition and well - equipped; refirigeration systcms present but some improvements required by applying hacep principles and also duc to good hyglenle praetices and high standard personal hyglene of applied quality assurance program. Nowadays, consumer attltudes towards food safety have started to evolve and both the local and export market are becoming Increasingly stringent about food quality and safety.
Vice versa, In plant (B) most samples recorded higher number than plant (A) although results witin (ES) but these results were recently obtained after processing microorganisms can inuluply because animal products should be stored at low temperatures to prevent microbtal proliferation this held the vlew reported by (Springer, 1993). Out obscruation, plant (B) store saw materlals and end-products at freezing tempcratures except for processed and sold at amblent tcmperatures.

Guidelines for fresh meat products consider a total aerobic in excess of $5 \times 10^{6}$ organIsms/g as a bad Indication (Janewalt and Guy, 1880).

Nearly similar results recorded by ouf (2001) and El- Mossalaml (2003).

This also may be attributed to the commltment of management and employees: environment, waste disposal. design of storage and preparation rooms not taken care of control of operations good; food handlers glven little facllitles and have poor hyglenelevel, require many Improvements. This is in-accordance with that reportcd by Nytelingum et as 2000).

In pant B staphylococcus aureus was present in high incldence (70\%) of ninal burger product samples. Bang et al. (2008) reported that Staphylococcus aureus contamination and enterotoxin production is a potentlal food safety hazard, nearly simllar results obtalned by Ouf (2001) and Elelwa (2003). In practice what can be seen in plant (B) an employee happily picking his nose while walung 
for production line. Rules are being Ignored whilst management complain about the cost of providing clean protectlve clothing dally. The whole system Is conduclve to microblological growth. This habits in plant (B) illustrate why the rcsults of Staphylococcus aurcus is highly positive. Staphylococd are present in the nasal passages and throats and on the halr and skin of 50 percent or more of healthy Individuals FDA (2005).

Our results revealed that (plant A) was lower than plant (B) in APC of workers, walls and machines respectlvely that is due to the $\mathrm{m}$ crobial quality of processing factorics from slaughtering to retall display. This supported by Andings reportcd by (Greer and Jeremain, 1980).

Food-handling personnel play an important role In ensurng food safety throughout the chain of production. processing. storage and preparation. Mishandling and disregard of hyglenlc measures on thcir part may enable pathogens to come into contact with food and. in some cases to survive and multiply in sufficient numbers to cause illness In the consumer (WHO, 1980).

Mishandling of food as well as uncleaned equipment surfaces wcre the most sources of contamination (Bryan and Lyon, 1984).

Rules about washing hands before contactIng foods, use of utensils to handle products. disposable gloves, clean clothes, and protected halr need to be applled regardicss of the slze of the operation.

The compllance of employees with good manufacture practice (GMP), cleaning and sanitation program were the maln control points at this step. So, the hyglenic measure of utensils and employees were examined. Recently food borne illness was increased from the consumption of meat and meal products which were contaminated with human bacteral pathogens.

There-fore, they constitute public health hazard as well as economic losses throughout thcir deteriaration.

Heat treatment had a significant effect on bacterlological quality of the beef burger. It is gcnerally accepted In meat hyglene that meat used for human consumption should be free from pathogenic microorganisms and may contain the least number of non pathogenic microorganisms.

Meat products may be eontaminated with microorganisms from meat handlers who are carrying of these pathogenlc mlcroorganisms during manufacturing packaging and marketIng of these products. Improper cooking. refrigeration or storage may lead to meat bome illness.

Inadequate cooking cause several outbreaks of foodbornc diseases In England and Wales. United Statc and New South Wales and Australia (Bryan 1978; Roberts, 1982 and Davey, 1886).

The present data that (plant A) indicated that cooking minimize APC. Therefore the results were lower than those obtained by (De Curtis et al. (2000) and Pruett et al. (2002). Also plant (B) revealed that APC higher than 
plant (A) but it is also decreased due to cookIng.

Grilling the meat pattles in clamshell grill at constant temperature (Higer plate Temperature $218^{\circ} \mathrm{C}$ and lower surface temperature $177^{\circ} \mathrm{C}$ and constant time $43 \pm 2$ seconds to the destruction at pathogen is achicved by cooking the meat to at least $66^{\circ} \mathrm{C}$ inadequate cooking cause several out breaks of lood born diseases.

It is recommended that the advice to cook burgers untll the julces run clear and there are no plnk bits Inside.

A high APC values does not constitute a risk to health but In a cooked product it may
Indlcate an overall lack of hyglene.

Hyglene could be assessed through (GMP) which include temperature control, cleaning and disinfection, and food handlers for plant (B).

Some recommendations are formulated at varlous levels to improve hyglene in both plants. At the level of the fond industry, internal hygiene eontrol in the food industry ean be implemented. specially through voluntary control programmes at the institutional level.

In eonclusion we should apply system from stable to table based on HACCP and good manufacturing practice for all stages of production and handling of burger. 
Table (1): Results of bacteriological examinatton of froxed raw meat samples in two meat processteng plants compared with Eeyptian standard (ES-2005):

\begin{tabular}{|l|c|c|c|}
\hline \multicolumn{1}{|c|}{ Criteria } & Plant (A) & Plant (B) & ES limit \\
\hline Aeroble plate count: & $1.1 \times 10-2.4 \times 10^{2}$ & $1.3 \times 10-3.1 \times 10^{2}$ & $10^{3}$ \\
- Range & $5.5 \times 10 \pm 1.1 \times 10$ & $6.28 \times 10 \pm 1.32 \times 10$ & \\
- Mean \pm SE & 0 & $20 \%$ & \\
\hline Incldence \% of pathogens: & 0 & 0 & \\
\hline - Staphylococcus aureus. & $0.449(0.656)$ & $0.337(0.738)$ & \\
\hline
\end{tabular}

Table (2): Results of bacteriological examination of final product samples in two meat processing plants compared with Egyptlan standard (ES):

\begin{tabular}{|l|c|c|c|}
\hline \multicolumn{1}{|c|}{ Criteria } & Plant (A) & Plant (B) & ES limit \\
\hline Aeroblc plate count: & $2.4 \times 10^{2}-2.6 \times 10^{3}$ & $2.4 \times 10^{4}-3.5 \times 10^{5}$ & \\
- Range & $8.71 \times 10^{2} \pm 1.44 \times 10^{2}$ & $10.82 \times 10^{4} \pm 1.73 \times 10^{4}$ & $10^{5}$ \\
- Mean \pm SE & 0 & $70 \%$ & \\
\hline Inctdence \% of pathogens: & 0 & 0 & \\
\hline - Staphylococcus aureus. & $6.190^{\circ}(<0.001)$ & $8.277^{\circ}(<0.001)$ & \\
- Salmonella. & & & \\
\hline
\end{tabular}

: Student t-test

- Statistically significanl at $\mathrm{p} \leq 0.05$ 
Table (3): Resuits of total colony count of workers, walls and machines, in two processing plants

\begin{tabular}{|l|c|c|c|}
\hline & Workers $(\mathbf{n}=25)$ & Walls $(\mathbf{n}=25)$ & Machines $(\mathbf{n}=25)$ \\
\hline Range & $1 \times 10-1 \times 10^{2}$ & $0.00-10.00$ & $0.00-10.00$ \\
Mean \pm SE & $4.4 \times 10 \pm 0.62 \times 10$ & $5.2 \pm 1.02$ & $6.4 \pm 0.98$ \\
\hline Range & $1 \times 10^{2}-1 \times 10^{5}$ & $0.00-10.00$ & $1 \times 10-1 \times 10^{3}$ \\
Mean \pm SE & $3.68 \times 10^{3} \pm 2.014 \times 10^{3}$ & $6.4 \pm 0.98$ & $2.58 \times 10^{2} \pm 7.6 \times 10$ \\
\hline $\mathbf{t}(\mathbf{p})$ & $1.806(0.077)$ & $0.849(0.400)$ & $3.313(0.003)$ \\
\hline
\end{tabular}

t: Student t-test

* : Statistically significant at $\mathrm{p} \leq 0.05$

Table (4): Total colony count of fnal product of burger (after grill) in two processing plant.

\begin{tabular}{|l|c|c|}
\hline \multicolumn{1}{|c|}{ Criterla } & Plant (A) & Plant (B) \\
\hline - Range & $0-8$ & $1 \times 10-8 \times 10$ \\
- Mean \pm SE & $2.28 \pm 0.47$ & $3.88 \times 10 \pm 0.44 \times 10$ \\
\hline
\end{tabular}




\section{REFERENCES}

APHA (1982) : Amencan Public Health Assoclation Compendium of Methods for the Mieroblological Examination of Foods. 3rd Ed. Washing. D.C., USA.

Badawy, A. B. A. (2004) : Quality assuranee of imported frozen meal. M. V. Scl., Fac. Vct. Med., Alexandria Univ.. Egypt.

Bang, W. I., Hasson, D. J. I. and Drake, M. A. I. (2008) : Effect of salt and sodlum nltrite on growth and enterotoxdn produetion of Staphylococcus aureus during the production of Alr-Drled Fresh Pork Sausage, J. Food Prot. 71, 191.195.

Bryan, F. L. (1878) : Factors that eontribute to outbreaks of foodbom diseases, J. Food Prot. 41: 816-827.

Bryan, F. L. and Lyon, J. B. (1984) : Critleal control points of hospltal food service operations. J. Food Prot. 47:950.

Davey, G. R. (1985) : Food poisoning in New South Wales: 1977-84 Food Technology in Australia, 37, 453-456.

De Curtis, M. L.; FrancegchI, O. and De Cagtro, N. (2000) : Assessment of interoblological quallty of lood served in dining rooms of private enterprises. Arch Latinoam Nutr. 50: $177-82$.

Egoptian Standard Legislation (2008) : Egyptian Organtzation for Standardization and Quality Control. Egyptlan Standard SpecIflcation for Burger: 1688-2005.
El-Mossalam, E. I. K. (2003) : Risk assessment of ready-prepared meat products. Ph. D. Thesls, Fae. Vet. Med., Calro Unlv.

FDA (2008) : Staphylococcus aureus. Bad Bug Book. Foodborne Pathogenlc MicroorganIsms and Natural Toxdns Handbook (1992) updated 2005), USFDA/FDA, Center for Food Salety \& Applled NutritJon.

Greer, G. G. and Jeremaln, L. E. (1880): Effect of retail sanitation on the bactenal load and shell life of beef. J. lood proteet. 43:277.

ICMSF (1996) : Mlcroorganisms In Food, Vol. 1, their signifieance and methods of enumeracion. 2nd Ed. Univ. Toronto press. Toronto Canada.

Janewalt, C. and Guy. (1980) : Relation of microblai quallty of retall meat samples and sanitary condition. J. Food protect 43:385.

Ouf, J. M. M. (2001) : Microorganisms of sanitary Importance in some meat products and thelr additlues. Ph. D.Thesis Fac. Vet. Med. Calro. University.

Marriot, G. N. (1994) : Prinelples of Food Sanitation. Chapman and Hall. New York.

Mohammed, M. M. B. (1997) : Quallty studics on the market frozen meat product M.V.Sc. Thesis (Meat Hyglene), Fac. Vet. Med. Calro University.

Elelwa, E. H. E. (2003) : Effect of chemical preservatives on food polsoning bacterla in 
some locally-manufactured meat products. Ph. D., Fac. Vet. Med., Moshtohr, Zagazlg University.

Pruett. W. P. Jr.; Blela, T.; Lattuada, C. P.: Mrozingki, P. M.; Barbour, W. M.; Flowers, R. S.; Osborne, W.: Reagan, J. O.: Theno, D.: Cook, V.; MeNamara, A. $M$. and Rose, B. (2002) : Incldence of Escherichia coll 0157:H7 in frozen beel pattles produced over an 8-hour shift. J Food Prot. 65: 136370.

Roberts, D. (1982) : Factors contributing to outbrcaks of lood polsoning in England and Wales 1970-1979. Joumal of Hyglene, 49198.

Springer, R. A. (1993) : Hygiene for Managcment: a text for Food Hygiene Courses. HIghfleld Publications. U.K.

Tolba, K. 5. (1994) : Microhora in locallyprocessed frozen meat. Vet. Med. J. Giza. 42 99.
Vasslllladis, P.; Tripchopoulos, D., Pateraki E. and Papalcano-Mou, N. (1983) : Isolation of Salmonella from minced meat by the used of a new procedure of entchement, Zentrablatt Ear Bacteriologle, Parasitea Und Infectlons Krankhelten Und. Hygiene. B 166: 81.

who (1980) : "Health examination of food-healing personnel" Report of workdng group Copenhagen. WHO Reglonal Ofnce for Europe.

WHO (2000) : "Foodborne disease: A focus for health educatlon", Geneva.

Yasslen, N. A (1988) : Sanitary Improvements of locally-manufactured meat products. Ph. D., thcsis, (Meat Hyglene), Fac. Vet. Med.. Calro University.

Vytelngum, S. A: Goburdhun, D. and Rugs. A O. O. (2000) : An Asscssment of the hyglene levcl in animal product processing plants in Maurtitus. Scienee and Technology Research Sournal 83-104. 


\section{الملخص العريى}

\section{تقبيم الجسـردة الصحيحة للبرجـر في مصنعين بمحانظــة الإسكندريسة

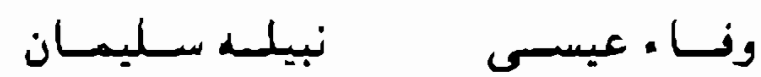

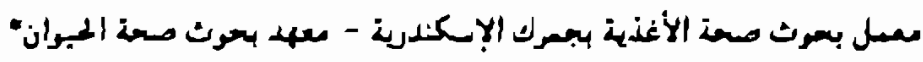

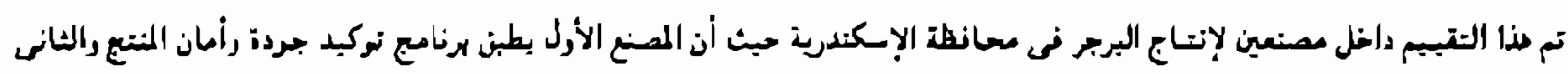

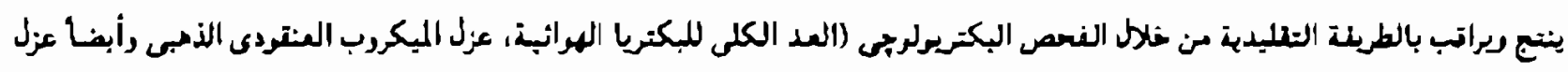

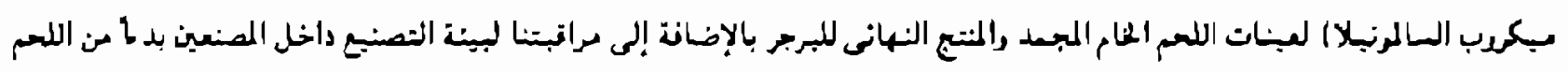

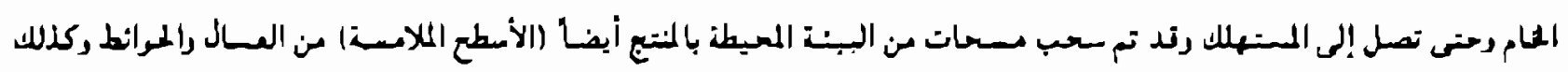

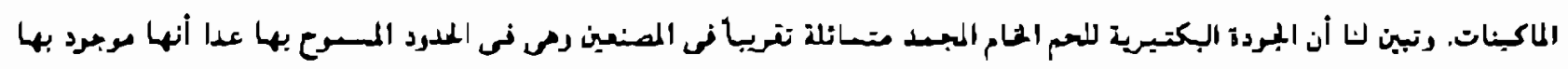

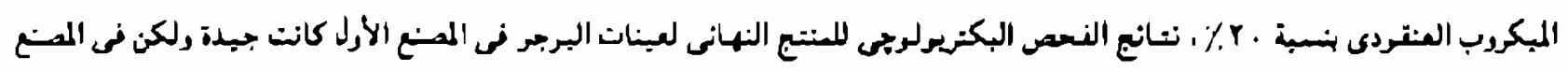

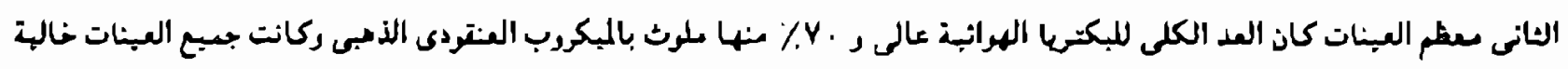

$$
\text { من ميكروب السالمرنيلا. }
$$

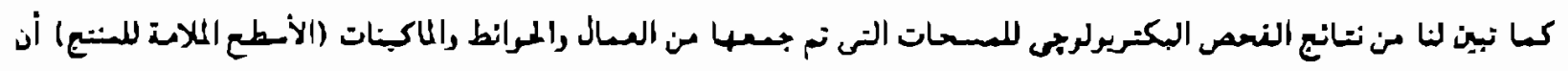

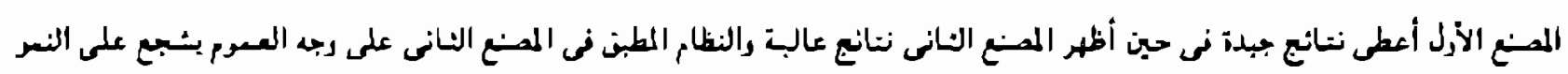

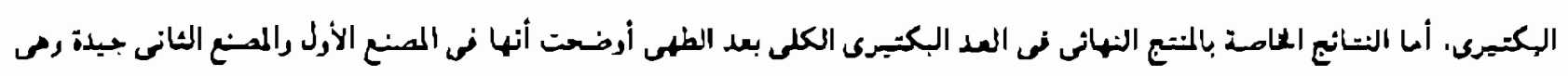

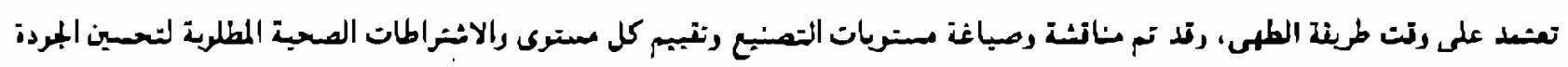
العسية فى كلا المـعبن لإنساج متتج آمن رعالمى الجهردة. 